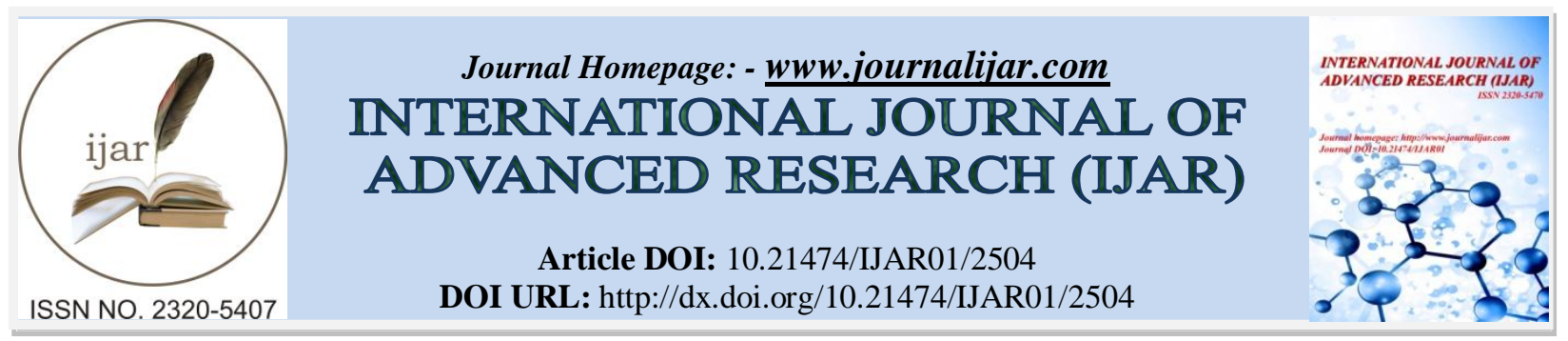

RESEARCH ARTICLE

\title{
ANTIDIABETIC EFFECT OF SOME MEDICINAL PLANTS BARK, LEAF AND SEED EXTRACTS IN STREPTOZOTOCIN INDUCED DIABETIC RATS.
}

\author{
S. MD. Abdul Razak ${ }^{1}$, Mohammed Elyas ${ }^{1}$, Tara Thomas ${ }^{1}$ and Zahoorullah. S. MD ${ }^{2 *}$. \\ 1. Department of Medicine, Fathima Institute of Medical Sciences, Ramarajupalli, Pulivendula Road, Kadapa, \\ Andhra Pradesh-516003. \\ 2. Department of Biotechnology, Joginpally B.R Engineering college, Yenkapally, Moinabad Mandal, Ranga \\ Reddy District, Hyderabad, Telangana-500075.
}

\section{Manuscript Info}

\section{Manuscript History}

Received: 25 October 2016

Final Accepted: 23 November 2016

Published: December 2016

Key words:-

Antibacterial, Diabetic, Ethanolic,

Sunflower, Tulip.

\section{Abstract}

Many medicinal trees and plant extracts of bark, leaf and seeds are in use as antibacterial, hepatoprotective, haemostatic, astringent, antidiarroheal and anti-inflammatory. Thespesia Populnea is known as Indian tulip tree and belongs to Malvaceae family of plant kingdom. It is distributed in coastal forest and tropical regions in India. On the other hand Helianthus annuus L., commonly known as sunflower, seeds are utilized for antidiabetic effect in Indian system of medicine. In the present review paper, both the plant extracts are compared and their uses were summarized. The ethanolic extract of the plant bark, leaf and ethanolic extract of sunflower seeds evaluation studies for their effect against the streptozotocin (STZ)-induced diabetic rats are discussed.

Copy Right, IJAR, 2016,. All rights reserved.

\section{Introduction:-}

Diabetic mellitus (DM) is the condition arising due to abnormal metabolism of carbohydrates, proteins and fats. It is caused by insulin deficiency, often combined with insulin resistance [1]. This disorder occur world wide and its occurrence is increasing quickly in most of the countries. Various complications develop as a consequence of the metabolic derangement in diabetes [2]. The treatment of DM is based on parenteral insulin and oral anti-diabetic drugs. Currently used Oral hypoglycemic agents have serious side effects, hence there is a need to search a newer anti-diabetic agents that are having high therapeutic efficacy with minimum side effects [3].

This may be fulfilled by treating DM with traditional medicine using anti-diabetic agents from medicinal plants. It is estimated that there are 171 million people in the world with diabetes by the year 2000 and this is likely to increase up to 366 million by the year 2030 [4]. There are various herbs which are used for the treatment of diabetes mellitus. Large number of plants have been explored for their antidiabetic potential, for e.g Cyompsis tetragonoloba [5], Cichorum intybus [6], Ficus carica [7], Picralima nitida [8], Phyllanthus amarus [9], Abutilon indicum [10], Clausena Anisata, [11], Alpinia galangal [12] etc.

At present, nearly 222 clinical trials investigating the effects of antidiabetic plants on diabetic patients are undergoing [13]. However from 1950 to 1970, only five drugs of plant origin were successfully tested in clinical phases and came in to market [14]. Therefore, it is necessary to search for new drugs and interventions that can be used to manage this metabolic disorder. Thespesia populnea ex correa (family malvaceae) is a large tree found in 
the tropical regions and coastal forests in India and cultivated in the gardens. All the parts of the plant are used in traditional system of medicine. The bark, leaves, flower and fruits are useful in cutaneous infection such as scabies, psoriasis, eczema, ringworm, and guinea worm.

The decoction of the bark is commonly used for the treatment of skin and liver diseases. A compound oil of bark and capsules are useful in urethritits and gonorrhea. The bark, root, fruits were used in dysentery, cholera and hemorrhoids [15]. The fruits of the plant are used in ayurveda for the control of diabetes [16]. An ayurvedic preparation contains Thespesia populnea, namely "panchvalkala" posses' free radical scavenging activity [17]. The barks and flowers posses astringent, hepatoprotective, antioxidant and anti-inflammatory activities in rats[18],[19],[20],[21] and also supposed to improve the memory [22].

Helianthus annuus $\mathrm{L}$. is a coarse, stout and erect annual plant which is 1-3 meters high. It produces greyish green or black seeds encased in tear-dropped shaped grey or black shells that often times featured black and white strips. Seeds encased in plant contains monoterpenes ( $\alpha$-pinene, Sabinene) [16-17], diterpenes (Helikauranoside) [18], oleic acid, triacyl glycerol, alkaloids, cyanogenic glycosides, saponins, cardiac glycosides, tannins, fixed oils, flavanoids [19], sesquiterpenes lactones [18] and alkaloids [20]. Flowers contain quercimeritrin, anthocyanin, abundant amount of cholin and betain, triterpene [21] and saponins [22]. Seeds contain 45 to 48 percent fixed oil, tannins [23] and polyphenols [24]. Helianthus annuus L. is a folk remedy for bronchiectasis, bronchitis, carbuncles, catarrh, cold, colic, cough, diarrhoea, dysentery, dysuria, epistaxis, eyes, fever, flu, fractures, inflammations, laryngitis, lungs, malaria, menorrhagia, pleuritis, rheumatism, scorpion stings, snakebite, splenitis, urogenital ailments, whitlow and wounds [25].

\section{Antidiabetic activity of Thespesia Populnea bark and leaf extracts:-}

R. Parthasarathy et al., 2009 demonstrated that the ethanolic extract of Thespesia populnea bark and leaf was investigated for hypoglycemic effect in steptozotocin induced diabetic rats and compared this effect with glibenclamide, a standard hypoglycemic agent and also measured the lipid peroxide, superoxide dismutase and catalase enzyme levels in the liver and kidney of the animal.

The preliminary phytochemical studies indicated the presence of carbohydrate, protein, tannins, phenol, flavonoids, terpenes, saponins and gums in the ethanolic extract of the bark and leaf. In acute toxicity study, the ethanolic extract of Thespesia populnea bark and leaf did not produced lethality up to the dose level of $2000 \mathrm{mg} / \mathrm{kg}$. In the antidiabetic activity, the blood sugar levels were measured in first to six groups of experimental rats in initial and at the 5, 10 and 15 days of treatments. Streptozotocin induced diabetic rats showed significant increase in the level of blood sugar. Oral administration of bark extract and leaf extract at the dose of $400 \mathrm{mg} / \mathrm{kg}$ body weight showed the significant decrease $(\mathrm{P}<05)$ on blood sugar level in 10 to 15 days of treatment (Table 1$)$.

Antidiabetic effect of Helianthus annuus L., seeds:-

Shivani Saini and Sunil Sharma,2013 demonstrated that the antihyperglycemic effect of ethanol extract at $250 \mathrm{mg} / \mathrm{kg}$ and $500 \mathrm{mg} / \mathrm{kg}$, studied in streptozotocin (STZ) induced type2 diabetic rats comparing the results with normal, glucose loaded hyperglycemic. A significant low levels in blood glucose of normal glycemic rats $(\mathrm{P}<0.05)$ are shown by administration of alcoholic extract of Helianthus annuus L. at two dosages $250 \mathrm{mg} / \mathrm{kg}$ and $500 \mathrm{mg} / \mathrm{kg}$, p.o. respectively. A reduction in blood glucose levels $(\mathrm{P}<0.01)$ is observed in diabetic rats with oral glucose tolerance test.

Administration of seeds extract in streptozotocin-nicotinamide induced diabetic rats have shown a significant decrease in the blood glucose level $(\mathrm{P}<0.001)$ compare to Glibenclamide $(600 \mu \mathrm{g} / \mathrm{kg})$. It has restored the lipid profile, showed improvement in body weight, plasma malondialdehyde, glutathione level, liver glycogen content, glycosylated haemoglobin and serum insulin levels in diabetic rats (Table 2). 


\section{Conclusion:-}

The ethanolic extract of Thespesia populnea bark and leaf exhibited significant antihyperglycemic activity in streptozotocin (STZ)-induced diabetic rats. The study demonstrated the potential antidiabetic property of ethanolic extract of Helianthus annuus L. seeds in Type2 diabetes mellitus. Chlorogenic acid present in seeds is reported to have antidiabetic effect. Present efforts are directed to isolate active constituent from the plant extract and confirmation of mechanism of action. The result of this experimental study indicates that both the ethanolic extracts of Thespesia populnea bark and leaf, Helianthus annuus L. seeds extracts posses' anti-diabetic effect against STZ induced diabetic rats causing a reduction in diabetes and its complications.

Table 1 Antidiabetic activity of Thespesia Populnea bark and leaf extract against streptozocin induced diabetic rats:

\begin{tabular}{|c|l|c|}
\hline \multirow{2}{*}{$\begin{array}{c}\text { Sr. } \\
\text { No: }\end{array}$} & \multicolumn{1}{|c|}{ Groups } & \\
\cline { 3 - 3 } 1 & STZ & $15^{\text {th }}$ Day \\
\hline $\mathbf{2}$ & TPLE 200 & $208.66 \pm 9.11 \alpha$ \\
\hline $\mathbf{3}$ & TPLE 400 & $196.83 \pm 7.70 \alpha$ \\
\hline $\mathbf{4}$ & TPBE 200 & $214.16 \pm 6.55 \alpha$ \\
\hline $\mathbf{5}$ & TPBE 400 & $189.50 \pm 6.92 \alpha$ \\
\hline $\mathbf{6}$ & Std Glibenclamide & $123.66 \pm 9.11 \alpha$ \\
\hline
\end{tabular}

Table 2: Helianthus anuuus L. on fasting blood glucose in STZ-induced diabetic rat:

\begin{tabular}{|l|l|}
\hline & $\mathbf{1 4}^{\text {th }}$ \\
\hline Normal & $85.2 \pm 1.02$ \\
Control & $331.58 \pm 6.24$ \\
Glibenclamide & $165.72 \pm 4.74^{* * * *}$ \\
Diabetic+HAE $(250 \mathrm{mg} / \mathrm{kg})$ & $229.62 \pm 4.55^{* * * *}$ \\
Diabetic+HAE $(500 \mathrm{mg} / \mathrm{kg})$ & $185.08 \pm 3.05^{* * * *}$ \\
\hline
\end{tabular}

The values are expressed as mean \pm SEM. $n=6$ animals in each group Statistical significant test for comparison was done by ANOVA, followed by Dunnett's t-test. The blood glucose values of groups are compared with normal control animals, values ${ }^{*+*} \mathrm{p}<0.001,{ }^{* t} \mathrm{p}<0.01,{ }^{+} \mathrm{p}<0.05$.

The values are mean \pm SD of 6 animals in each grou. Statistical analysis was carried out by paired sample t-test $\alpha$ P $\alpha 0.05$, N.S. non significance.

Table 1 \&2 : Values obtained from R. Parthasarathy et al., 2009 [23] and Shivani Saini and Sunil Sharma,2013 [24].

\section{References:-}

1. World Health Organization., WHO Study Group of Prevention of Diabetes Mellitus, WHO Tech Ser, 1994, $844,11$.

2. Siddharth NS., Containing the global epidemic of diabetes, J. Diabetol., 2001, 3, 11.

3. Holman R.R, Turner R.C., Oral agents and insulin in the treatment of NIDDM, In. J. Pickup and G. Williams, Editors, Text Book of Diabetes, Blackwell, Oxford, 1991, 467-469.

4. Gerstain HC, Santaguida P, Raina P, Morrison KM. Diabetes Research and Clinical Practice 2007; 78: 305-312

5. Bhandari V, Sharma JN. Effect of petroleum ether extract of guar gum in STZ induced hyperglycaemic rats. Pharmceutical Biology 1999; 37: 248-250.

6. Ki CG, Yim DS, Lee S. Biological activities of the root of Cichorium intybus. Natural Product Sciences 1999; 5: $155-158$.

7. Perez C, Deminguez E, Canal JR. Hypoglycaemic activity of an aqueous extract from Ficus carica leaves in STZ diabetic rats. Pharmaceutical Biology 2000; 38: 181-186.

8. Agawa CN, Ukwe CV, Inya-Agha SI. Antidiabetic effect of Picracima nitida aqueous seed extract in experimental rabbit model. Journal of Natural Remedies 2001; volume 1/2: 135-139.

9. Raphael KR, Sabu MC, Kutttan R. Hypoglycemic effect of methanol extract of Phyllanthus amarus on alloxan induced DM in rats and its relation with antioxidant potential. Indian Journal of Experimental Biology 2002; 40: 905-909.

10. Seetharam YN, Setty SR, Chalegeri G. Hypoglycemic activity Abutilon indicum leaf extracts in rats. Fitotherapia. 2002; 73: 156-159. 
11. Ojenole AO. Hypoglycemic effect of Clausena anisata methanolic root extracts in rats. Journal of Ethanopharma-cology. 2002; 81: 231-237.

12. Akhtar MS, Khan MA, Malik MT. Hypoglycemic activity of Alpinia galangal rhizome and its extracts in rabbits. Fitotherapia 2002; 73: 623-628.

13. Shojaii A, Goushegir A, Dabaghian FH, Abdollahi M, Huseini HF. Herbs and herbal preparations for glycemic control in diabetes mellitus (a systematic review). Journal of Medicinal Plants Research 2011; 16: 3846-3855.

14. Evans JL, Goldfine ID, Maddux BA, Grodsky GM. Oxidative stress and stress-activated signaling pathways: a unifying hypothesis of type 2 diabetes. Endocrine reviews 2002; 23: 599-622.

15. The wealth of India., Publication and Information directorate (CSIR), New Delhi, 1995, 223-275

16. Satyanarayana T., Sarita T., Balaji M., Ramesh A., Boini M.K., Anti-hyperglycemic and hypoglycemic effects of Thespesia Populnea fruits in normal and all oxan-induced diabetes in rabbits, Saudi pharmaceutical journal, 2004, 12, 107-111.

17. Sheetal anandjiwala., MS Basnl., M Parabia., M Rajani., Evaluation of free radical scavenging activity of an ayurvedic formulation, Panchvalkala, Indian journal of pharm.sciences, 2008, Nov.91, 70, 31-5

18. Illavarasan R., Vasudevan M., Anbazhagan S., Venkataraman S., Antioxidant activity of Thespesia Populnea bark extracts against carbon tetrachloride induced liver injury in rats, J. Ethanopharmacology, 2003 , Aug 87 (23), 227-230.

19. Ilavarasan, R., Vasudevan, M., Anbazhagan S., Venkataraman S., Sridher, S.K., Hepatoprotective activity of Thespesia Populnea bark extracts against carbon tetrachlorideinduced liver injury in rats, Natural Product Sciences, 2003; 9, 83-86.

20. Shirwaikar A., Kumar A.V., Krishnanand B.R., Sreenivasan K.K., Chemical investigation and antiheptotoxic activity of Thespesia Populnea, International journal of Pharmcognosy, 1995, 33, 305-310.

21. Manivasudevan M., Kumar Kishore Gunman, Milind Parle., Antinociceptive and anti-inflammatory effects of Thespesia populnea bark extract. Journal of ethnopharmacology, 2007, 109, 264-270.

22. Vasudevan M., Parle M., Pharmacological action of Thespesia Populnea relevant to Alzheimer disease, Phytomedicine, 2006, Nov., 13 (9-10), 677-87.

23. R. Parthasarathy, R. Ilavarasan, C.M. Karrunakaran, "Antidiabetic activity of Thespesia Populnea bark and leaf extract against streptozotocin induced diabetic rats", International Journal of PharmTech Research, ISSN : 0974-4304, Vol.1, No.4, pp 1069-1072.

24. Shivani saini, Sunil Sharma, "Antidiabetic effect of Helianthus annuus 1., seeds ethanolic extract in streptozotocin- nicotinamide induced type 2 diabetes mellitus", International Journal of Pharmacy and Pharmaceutical Sciences, ISSN- 0975-1491 Vol 5, Issue 2, 2013. 